\title{
A ROAD TO ORGANiSATIONAL PERDITION? BUSINESS, ETHICS AND CORPORATE SOCIAL RESPONSIBILITY
}

\author{
DAL Coldwell
}

School of economic and Business Sciences, University of the Witwatersrand

Accepted March 2010

\begin{abstract}
The paper delineates a heuristic device comprising relationships between levels of instrumentality towards Corporate Social Responsibility (CSR) implicit in differential theoretical organisational approaches, associated managerial freedom in ethical decision making, and corresponding managerial moral orientations. Prominent theoretical approaches to CSR including: criticalism, fundamentalism, social corporatism, social institutionalism and moralism identified in the extant literature are delineated. These approaches are synthesised and articulated with the concepts of degrees of CSR instrumentality, ethical freedom and managerial moral orientations to produce a composite heuristic device with specific potential practical implementations. Ramifications of the analysis in terms of developing managers with ethical acumen and providing organisational circumstances allowing this to flourish are briefly discussed.
\end{abstract}

Keywords: Corporate social responsibility, moral, amoral, immoral management, instrumentality, criticalism, fundamentalism, social corporatism, social institutionalism, moralism.

JEL M14

\section{1}

\section{Introduction}

In reaction to the global financial implosion a recent edition of the Financial Times stated that: 'The world has gained a new appreciation for long-term risk, and regulators around the globe seek to impose new standards on institutions they supervise' (Masters, 2009: 1 emphasis added).

The question remains, however: could the credit crunch have been avoided had there been such standards in place beforehand? And, might future possibilities of a re-occurrence be expunged by such means? Although important questions, this paper is not directly concerned with offering a further, even partial, nonfinancial explanation of the recent credit crunch, although such explanations of the crisis are becoming more prevalent and convincing (see, for example, Tett, 2009), it takes the view that such standards would have done little to avoid the collapse of global financial institutions, or to provide protection from such a possibility in the future. Moreover, although a distinction has to be made between the catastrophic financial collapses of Enron and World-com which resulted from deliberate fraud rather than failures in systems; accounting, finance, law and management (Heinemann, 2009), it is an inescapable fact that systems fail more through human error than of their own accord and that this is often attributable to organisational pressure for profit and inimical management moral orientations.

As its central thesis the paper maintains that organisations may be on the road to perdition (financial implosion) when the following conditions are present:

- A business-like organisational approach to Corporate Social Responsibility (CSR) is evident such that managers are constrained to incorporate CSR 'instrumentally'(i.e. 
as a means to particular business ends) into the business agenda in a quest to enhance profits, with the degree of such instrumentality affecting management moral orientations, and

- Management has insufficient freedom to act ethically as a result of such instrumentalist company norms in situations requiring ethical flexibility (Foucault, 1978) and/or when they may be insufficiently morally developed (Kohlberg, 1981) to be able to do so effectively.

Instrumentality in CSR, the ethical core of a firm's interface with society, is affected by different generalised approaches the firm adopts in its use in business. These approaches have been theoretically described in the literature as, inter alia: criticalism, fundamentalism, social corporatism, social institutionalism and moralism.

In the argument to be unravelled in this paper it is maintained that when management's ethical orientation and scope for subjective ethical action is controlled by the requirements of organisations to use ethical behaviours, including those seen in CSR outlays and implementations, instrumentally, the freedom for contingent ethical behaviour among individual managers in other spheres of business action which, although not directly part of its ethical public face, may become diluted. If CSR is merely the manifestation of the business case for 'ethical' implementations, it becomes 'mauvais fois' in the fullness of Sartre's (1993) use of the term (i.e. as action being played out insincerely by management because that is what is required of it) and something that may eventually pervade other areas of management decision making. Furthermore, it is maintained that, a lack of subjective (existential) ethical freedom and the requirement made by organisations to use company ethical actions as a means to specific business ends, may increase the propensity for and legitimacy of 'mauvais fois' and lead to immoral managerial orientations that generate increasing levels of organisational risk.

A heuristic approach plotting relationships between levels of instrumentality in corporate social responsibility behaviours and their corresponding managerial moral orientations is discussed in the paper using various prominent theoretical approaches to CSR. These approaches are then synthesised and articulated with degrees of CSR instrumentality and managerial moral orientations to produce a composite heuristic device with specific possible organisational ramifications. Practical outcomes of the model regarding the development of ethically oriented managers and the provision of an organisational climate that allows this to take root are also briefly discussed.

\section{2 \\ Research methodology}

The study adopts an exploratory, partially unstructured design (Ghauri \& Gronhaug, 2002) involving an analysis of secondary data (literature review). The research method involves an analysis of the literature in terms of a proposed heuristic device describing particular levels of instrumentality associated with specific management ethical orientations, as defined by particular theoretical approaches to CSR.

3

\section{Literature review}

There are basically four distinct sections to the literature review which correspond to the main elements of the heuristic device (described in detail later in the paper). The first section deals with definitions of CSR and the rationale for the particular definition adopted in the paper. The second section deals with a review of pertinent theoretical approaches to CSR, and the third section with managerial moral orientations and levels of moral development. The fourth section of the review briefly discusses managerial ethical freedom in relation to organisational constraints.

\subsection{CSR Definitions}

There are a large number of definitions of CSR available in the literature. In an exhaustive scholarly review, Dahlsrud (2006) indicates that there are thirty-seven definitions of CSR that have been adopted by twenty-seven different 
recent authors. In a thorough analysis of these definitions utilising frequency counts and ratios as analytical tools, Dahlsrud (2006) found five main definitional dimensions. These are the: stakeholder, social, economic, voluntariness and environmental dimensions which are defined by Dahlsrud (2006) as follows:

- The environmental dimension is the natural environment, incorporating: commitment towards creating a cleaner environment, environmental stewardship and environmental concerns in business operations.

- The social dimension is the relationship between business and society, such as: integration of social concerns in business operations, making contributions to a better society and the consideration of the impact of the business on communities.

- The economic dimension refers to its socioeconomic or financial aspects including: defining CSR in terms of business operations, contributions to economic development and preservation organisational profitability.

- The stakeholder dimension refers to stakeholders and stakeholder groups and focuses on the way organisations interface with employees, suppliers, customers and communities.

- The voluntariness dimension refers to ethical actions not prescribed by existing law such as actions by the organisation based on ethical principles or values.

Of these five dimensions, the stakeholder, social and economic dimensions obtained the greatest author utilisation ratios. Eighty-eight per cent of authors used stakeholder and social dimensions in their definitions and 86 per cent incorporated the environmental dimension. A further analysis by Dahlsrud (2006) reveals that all thirty-seven authors' definitions had one or more of these dimensions in their definitions of CSR, with 40 per cent of authors adopting all five dimensions and 99 per cent adopting three or more dimensions of CSR in their respective definitions (e.g. Lea, 2002; Frederick et al., 1992; and Van Marrewijk, 2003), while single dimensional definitions are given by WoodwardClyde (1999) and Pinney (2001).
In short, Dahlsrud's (2006) analysis indicates the difficulty in finding a definition of CSR that would be acceptable to all authors in terms of content and/or completeness. In this regard van Marrewijk (2003) based on his analysis of historical perspectives, philosophical discussions and change dynamics, has suggested that a single definition of CSR and corporate sustainability should be abandoned altogether. Van Marrewijk (2003) maintains that CSR definitions should be dynamic and specific to particular organisational levels of development, awareness and ambition. The upshot is that it becomes difficult and somewhat arbitrary to choose a definition that circumscribes the concept of CSR accurately and adequately and which does not at the same time seem random and eclectic. However, two specific definitions have been selected for purposes of the current study on the grounds that they encapsulate the general way the concept is used here. The first is given by Robbins (1994: 123) who defines corporate social responsibility (CSR) as 'a business firms obligation, beyond that required by the law and economics to pursue long-term goals that are good for society'. This definition emphasises the importance of social and voluntariness dimensions. The second offered by Boone and Kurtz (1994: 54) gives a more general definition: 'social responsibility is management's acceptance of the obligation to consider profit, consumer satisfaction and societal wellbeing of equal value in evaluating the firms performance.' The latter definition provides the fundamental starting point for its use in the current study because it emphasises the essential dichotomy of the ethical and profit dimensions of business. Both have important parts to play, but both should remain discrete otherwise there is a real possibility that purportedly ethical managerial behaviours become insincere (Bakan, 2004) and may become invoked simply to achieve specific business ends.

\subsection{Approaches to CSR}

The seminal work of Carroll (1991) delineates four basic theoretical approaches to CSR. Very briefly, at the base of this pyramid are economic responsibilities which provide the bedrock 
on which all other responsibilities depend. The clarion call of economic responsibility is singularly simple: 'be profitable'. The second level of her conceptual pyramid is dedicated to legal responsibilities and here the company is expected to abide by society's laws. Ethical responsibilities comprise the next tier in Carroll's (1991) model which requires organisations to act ethically in their business conduct. Specifically, firms have an obligation to society to conduct business in a just, righteous and fair way and avoid doing harm. At the apex of Carroll's (1991) model is philanthropic responsibilities. These are a company's social responsibilities to be a good corporate citizen and to contribute its skills and resources to community development and improvements in the quality of life. While important and authoritative, Carroll's (1991) model is largely descriptive of types of approaches to CSR rather than theoretical justifications for CSR and since it is the latter that comprises the main focus of the current paper, this will be developed in more detail in the ensuing discussion.

Windsor (2006) suggests that there are three key approaches to CSR. The first, ethical responsibility, promotes altruism, commitment to duty and a strong public policy that emphasises stakeholder rights. Second, economic responsibility advocates free business wealth creation unencumbered by government public policy. The third key approach according to Windsor (2006), is that of corporate citizenship. Here two types are distinguished: instrumental corporate citizenship which uses CSR as a strategic resource for enhancing corporate reputation and increasing profits, and ideal corporate citizenship which affirms ethical responsibility and universal human rights (Windsor, 2006).

Such theoretical approaches to CSR can be regarded as comprising a spectrum which, in terms of Bakan's (2004) typology, range from 'sincere' on the one hand to 'insincere' on the other. Thus, in terms of Bakan's (2004) 'sincerity divide', Criticalism (Freeman \& Liedtka, 1991, Brown \& Fraser, 2006), occupies the furthermost point of the insincerity axis. Here corporate usages for ethical actions in business, as seen in, for example, CSR reporting, sink to their lowest point of the divide. Criticalists such as Brown \& Fraser (2006) regard CSR reporting as a deliberately fabricated smokescreen behind which unethical managerial behaviour continues unchecked and where disinformation and 'green washing' emanates from carefully construed reporting which seeks to hide failures in business accountability and even blatant human exploitation.

The Fundamentalist's approach is best articulated by Friedman (1970) who regards business itself (i.e. the maximising of profits) as its only responsibility other than conforming to the basic rules of society and its ethical customs. Higher profits transform into higher taxes for government which has a solitary mandate (in democracies at least) to concern itself with acts of social responsibility. For fundamentalists it follows that all acts of social responsibility performed by business must be considered 'insincere' (Bakan, 2004) in so far as they are performed outside their considered sphere of responsibility and legitimate authority.

Carter and Burrit (2007: 18) regard social corporatism as a hybrid new approach which emphasises the 'business case' for CSR utilisation. Unlike the older type of corporate social responsibility action, where CSR was usually considered as an adjunct to rather than an integral part of corporate strategy, today's firms are encouraged to support social responsibility as a strategy to promote other corporate objectives. While there is no unequivocal empirical evidence of the relationship between CSR and profits, Kotler and Lee (2005), for example, suggest that CSR is an important strategic tool for increasing sales and market share, strengthening brands, enhancing corporate reputations, attracting and retaining high level human capital, decreasing operating costs and increasing a firm's appeal to investors and financial analysts. In terms of Bakan's (2004) 'sincerity divide' this approach might be regarded as neutral, i.e. as potentially either sincere or insincere. However, this seemingly innocuous approach tends to confuse elements of management's ethical responsibility with the 'business case' to the extent that it may create fertile ground for an ethical slippery slope, beginning with amoral and ending in immoral management behaviour. 
Social institutionalism considers business organisations as institutions with social responsibilities. This approach emphasises the importance of the social contract which emerges most notably from the philosophy of Hobbes, Locke and Rousseau. It is not a legal contract as such (though, of course it does have a legal aspect to it in the rules that are formed to support it) but describes interrelations between business and society, rights and duties of individuals, institutions and practices as being essentially contractual (Carter \& Burritt, 2007: 20). Carroll and Bucholtz (2000: 18) suggest that the business contract consists of rules and regulations that provide the framework in which business must operate and the shared understandings and expectations in the business/ society interface. The legitimacy of business depends on satisfying societal expectations and its continued operation requires that it functions in accordance with these since society has the capacity to withdraw legitimacy when business fails to meet its expectations. (O'Donovan, 2002, McMurtrie, 2005).

Business legitimacy rests ultimately in both society and stakeholder perceptions of its functioning, thus stakeholder theory is another interrelated aspect of social institutionalism (Carter \& Burritt, 2007). In short, the essence of social institutionalism is the recognition by business that a social contract exists between it and society and its stakeholders, and that business is responsible not only for the accumulation of profits but also the achievement of specific social objectives (Brown \& Frazer, 2006). In terms of Bakan's (2004) typology, social institutionalism is therefore 'sincere' in so far as it makes a clear distinction between business's responsibilities for generating profit on the one hand and achieving certain social goals on the other.

Moralism requires that business organisations be regarded as natural persons that should be held responsible for their decisions and actions (Klonoski, 1991). Essentially moralism demands that businesses are primarily run in ethical manner emphasising unselfish behaviour towards the development of a virtuous organisation run by righteous people (Carroll \& Buchholtz, 2000). Palazzo \& Scherer (2006) regard moralism as providing the necessary social legitimacy for the sustained survival and support of organisations, while Moir (2001) regards it as an opportunity cost incurred by business to compensate society for diverting scarce resources away from solving social problems. Clearly, in terms of Bakan's (2004) typology, moralism is firmly positioned in the 'sincere' section of the divide.

In fact, Windsor's (2006) three key approaches to CSR closely follow the typology discussed earlier. The first, 'ethical responsibility', runs parallel with moralism in that both approaches promote altruism, commitment to duty and a strong public policy emphasising stakeholder rights. Second, 'economic responsibility' reflects the approach of fundamentalism by advocating free business wealth creation unencumbered by government public policy. The third key approach according to Windsor (2006) is that of 'corporate citizenship'. Here two types are distinguished: 'instrumental corporate citizenship' which Windsor (2006) maintains uses CSR as a strategic resource for enhancing corporate reputation and increasing profits, and 'ideal corporate citizenship' which affirms ethical responsibility and universal human rights. These two concepts clearly bear a close resemblance to social corporatism and social institutionalism respectively. Windsor's (2006) interpretations of instrumental and ideal corporate citizenship can be linked to the approaches of social corporatism and social institutionalism in the following manner. Citizenship implies social connectivity while instrumentalism as used by Winsor (2006) is close in meaning to social corporatism's notion of the 'business case' used in justifying CSR applications. Social corporatism and instrumental citizenship both advocate that CSR should be used as a strategic tool to increase a company's reputation and through this, its profitability. Similarly, the ideal citizenship and social institutionalism both maintain the central importance of ethical/social responsibility in CSR. Criticalism is not included in Windsor's (2006) typology of approaches to CSR and this might be regarded as making his discussion incomplete. However, although criticalism is one theoretical approach to CSR, albeit an extreme one in that it regards CSR use as being characterised by a very high degree of insincerity and cynicism, it is also clearly one 
that most managers would not be prepared to acknowledge as a valid reflection of their own. On the other hand, many managers would be quite prepared to acknowledge their approach to CSR as being regarded as 'fundamentalist' or 'social corporatist' as many would regard these approaches appropriate in a business world that they regard as legitimately governed by self-interest and instrumentalism.

Basic managerial ethical orientations that roughly correspond to the various approaches described above, particularly as regards Bakan's (2004) sincerity divide, are described in the following section.

\subsection{Management's moral orientations}

Carroll and Buchholtz (2000) describe three basic types of management ethical orientations. The first, immoral management, describes managers whose general behaviour, decisions and actions are discordant with ethical beliefs. Immoral managers hold selfish and greedy motives that focus mainly or principally on personal or company gains. In addition, Carroll and Buchholtz, (2000: 108) suggest that immoral managers consider legal rules as inconvenient barriers that need to be shunned to obtain the illicit outcomes they desire and that this entails, 'profitability and organizational success at almost any price' (op.cit: 108).

The second type identified by Carroll and Buchholtz (2000) is moral management which conforms to high ethical and professional standards and strives to be fair, balanced and unselfish in its conduct. Moral managers do not pursue profits at the expense of the law or sound ethics. (Carroll \& Buchholtz, 2000: 110).

Third, there are amoral managers of which there are two types, intentional and unintentional. Intentional amoral managers do not include ethics in their decision making because they believe it has no place in business and that different rules apply to business than to other aspects of life. Thus ethical considerations are not an integral part of their business decision making. Intentional amoral managers are neither moral nor immoral since business is seen to operate with its own rules which remain outside the conventional moral rules of society.
On the other hand, Dion (2001) suggests that unintentional amoral managers are morally casual, carefree and unaware. Such managers lack moral sensitivity and do not think in moral ways; they are like bulls in a china shop, completely oblivious to ethical issues in particular situations. However, although amoral managers intentionally or unintentionally pursue profitability without ethical sensitivity, they commonly remain within the confines of the law and legal regulations.

The operating strategies of these three types of management are also quite distinct. Carroll and Buchholtz (2000) suggest that immoral managers driving dictum is: 'Can we make money with this action, decision, or behaviour, regardless of what it takes?' (emphasis added, op. cit: 108).

In contrast, moral management guiding dictum is: 'will this action, decision, behaviour or practice be fair to all stakeholders involved as well as to the organization?' (emphasis added, op. cit: 110). Moral managers believe that while profits are important, they will not be pursued at the cost of management's or the firm's integrity.

Amoral management's key guiding orientation is oblivious to ethical issues and asks simply: is it possible to make money by acting, deciding, or behaving in a particular way? (op. cit: 113). Although the amoral manager is intentionally or unintentionally insensitive to ethics, he/she will make money only legally.

Logically there can only be the three basic forms of moral orientation described by Carroll and Buchholtz (2000). However, as these authors also point out, the prevalence of the various types of orientation and their discreteness has not been empirically verified. Specifically, the 'population hypothesis' or the proposition that amoral managers are the most frequently found type of business manager, has not been demonstrated through empirical analysis and, as such, remains an untested hypothesis. Also, as Carroll and Buchholtz (2000) point out, it is perfectly possible that the three models of management may emerge at different times in response to various circumstances in the same manager. While the average manager may be amoral most of the time, he/she may change to moral or immoral modes on different 
occasions. Again this is a hypothesis that remains empirically untested. Despite this unresolved empirical issue, for purposes of this paper it is assumed that managerial moral orientations are more or less of one or other of the three distinct types delineated by Carroll and Buchholtz (2000) at any given time but it also recognises that a regression from moral to immoral orientations is potentially possible.

\subsection{Management's level of moral development}

Carroll and Buchholtz's (2000) discussion of managers' different moral orientations suggests that individual managers may have developed to differential levels of moral maturity. Although it is not the intention to present a thorough résumé of the available literature on theories of moral development, since Kohlberg's (1981) theory of moral development has been applied to managers it is deemed of particular relevance here. In this regard various researchers such as Post et al. (2001) and Rahim et al. (1999) have used Kohlberg's theory specifically to analyse the level of moral development of managers. Very briefly, Kohlberg (1981) maintains that there are three basic stages of moral development. The first, called the preconventional stage, defines a level of moral thinking generally found at the primary school level where emphasis is on obedience through punishment. Later at the pre-conventional level, children begin to develop a sense of individualism, instrumentalism and exchange in their relationships with the social world. This has been aptly called the 'seeking-ofrewards-stage' (Carroll \& Buchholtz, 2000). This aspect is further developed in the second or conventional stage of moral development which is the level of moral development generally found among most persons in society. The first level of this stage emphasises behaviour aimed at gaining the approval of others; a 'good boy/nice girl' stage of morality (Carroll $\&$ Buchholtz, 2000). The second level of the conventional stage is characterised by a morality focused on law and order. The final stage of development according to Kohlberg (1981) is the post-conventional stage which the majority of adults never attain. The first level at the post- conventional stage is characterised by '...an understanding of social mutuality and a genuine interest in the welfare of others' (Barger, 2000: 1). The second and final level of this, the most advanced level of moral development, is based on universal principles and the precepts of individual conscience (Barger, 2000). The important point to grasp for purposes of this paper is that many managers, in accordance with Kohlberg's (1981) theory, are likely to be found at the conventional level which, in terms of Carroll and Buchholtz's (2000) managerial moral orientation typology, would seem to approximate the amoral manager in so far as both operate within the confines and dictates of the law (the second level of the conventional stage). A corollary of this interrelation, if valid, is that relatively few managers are likely to have developed to the post-conventional (moral) stage, or to have remained fixed at the elementary pre-conventional (immoral-unlessclosely-monitored) stage of development. This suggests that the freedom or governance constraints under which different managers are allowed to make decisions with ethical ramifications will partly depend on their individual levels of moral development. It also brings into sharp focus the possibility that specific individuals who have been promoted to management/leadership positions in organisations may not have attained levels of moral development that are sufficient to allow them to display the integrity required for effective responsible leadership. Such individuals would therefore be expected to require more careful governance. This aspect is discussed in greater detail below.

\subsection{Management's ethical freedom}

Aside from Carroll and Buchholtz's (2000) typology described above, the issue of being ethical in organisational settings has taken various paths. Some writers have focused on the ways in which individuals adhere to ethical norms and mores and how such rules should govern organisational behaviour (Jackson, 2000; Warren, 1993). Other authors (Barker, 1993; Sims \& Brinkmann, 2003) regard managers 
who adhere to organisational norms and rules as putting the possibility of ethical decision making beyond their reach. A third group take a more intermediate position. As Ibarra-Colado et al. (2006: 46) put it: 'Here being ethical requires being a person whose individual moral responsibility leads one to be "morally assertive" so as to mediate corporate priorities. The individual is responsible for ethical behaviour and so organizations should avoid restricting individuality through rules and instead create an "empowering ethics" that enable people to realize and meet their ethical responsibilities' (emphasis added). This follows closely Foucault's (1984) notion of ethics as the 'conscious practice of freedom'.

For Foucault (1984) consciousness relates to the fact that the individual manager's ethical subjectivity is socially contextual and is not unconstrained or free in the sense of being outside or cut-off from relations with others and social institutions. Thus, as Ibarra-Colado et al. (2006: 48) put it; 'The moral predicament that managers face concerns the way that they bring morality to bear on their interaction with organizational rules and requirements. The processes of self formation at work show how the identity of the manager might be ethically constituted. Indeed one interpretation would have Foucault saying that by actively seeking to control the ethical behaviour of individual managers, organizations unwittingly restrict freedom and hence the possibilities for ethics' (emphasis added). This is particularly pertinent when CSR, the ethical heart of an organisation, is constrained to be used instrumentally by management to achieve business rather than social ends.

Just as scientific management imposed a managerial perspective that condoned the measurement of production processes in which human beings were an integral part in their use of time and motion studies that reduced human involvement to ethically unsustainable simple repetitive processes, so instrumentality conducted in the form of social corporatism condones the use of corporate social responsibility initiatives by management as a tool to increase the competitive advantage of the firm; or as criticalism suggests, as a sham to deflect public attention away from illicit organisational behaviour. In such situations managers are constrained to act unethically to sustain the material ends of the company above any other factor. It is this instrumental focus that impacts negatively on ethical freedom in organisations and creates an environment where managers are caught in a downward spiralling vortex in which they feel unable to act responsibly and impose their own moral will. It also relegates individual managerial actions to a place where the discourse between freedom and governability is effectively destroyed.

Having reviewed the most pertinent extant literature, it is now time to turn attention to a more detailed account of the proposed heuristic.

\section{4}

\section{The development of a heuristic of interrelationships}

A heuristic device delineating the relationship between ethical instrumentality in CSR and management's moral orientations with the objective of synthesising the various aspects of the secondary data review can be best described diagrammatically. Such a diagrammatic representation illustrating its essential ingredients and articulations is presented in Figure 1.

Figure 1, indicates, along the vertical axis of the diagram, levels of instrumentality towards CSR (low to high) and corresponding managerial moral orientations ranging from weak (immoral) middling (amoral) and strong (moral) along the horizontal axis of the diagram. A downward sloping curve suggests, ceteris paribus, that as levels of ethical instrumentality decline towards CSR, managerial moral orientations strengthen, and conversely, as ethical instrumentality increases management's moral orientations weaken. The corresponding levels of managerial freedom in ethical (CSR) decision making which have not been included in Figure 1 for the sake of simplicity, run converse to specific levels of instrumentality. Thus management's ethical freedom in decision making is low when CSR instrumentality is high and, vice versa, high when CSR instrumentality is low. The 'exploded' regions of the diagram indicate the main approaches, justifications and critiques for the use of CSR in the corporate domain. 


\section{Figure 1:}

A heuristic device indicating interrelationships between approaches to CSR, corresponding levels of instrumentality in CSR and managerial moral orientations.

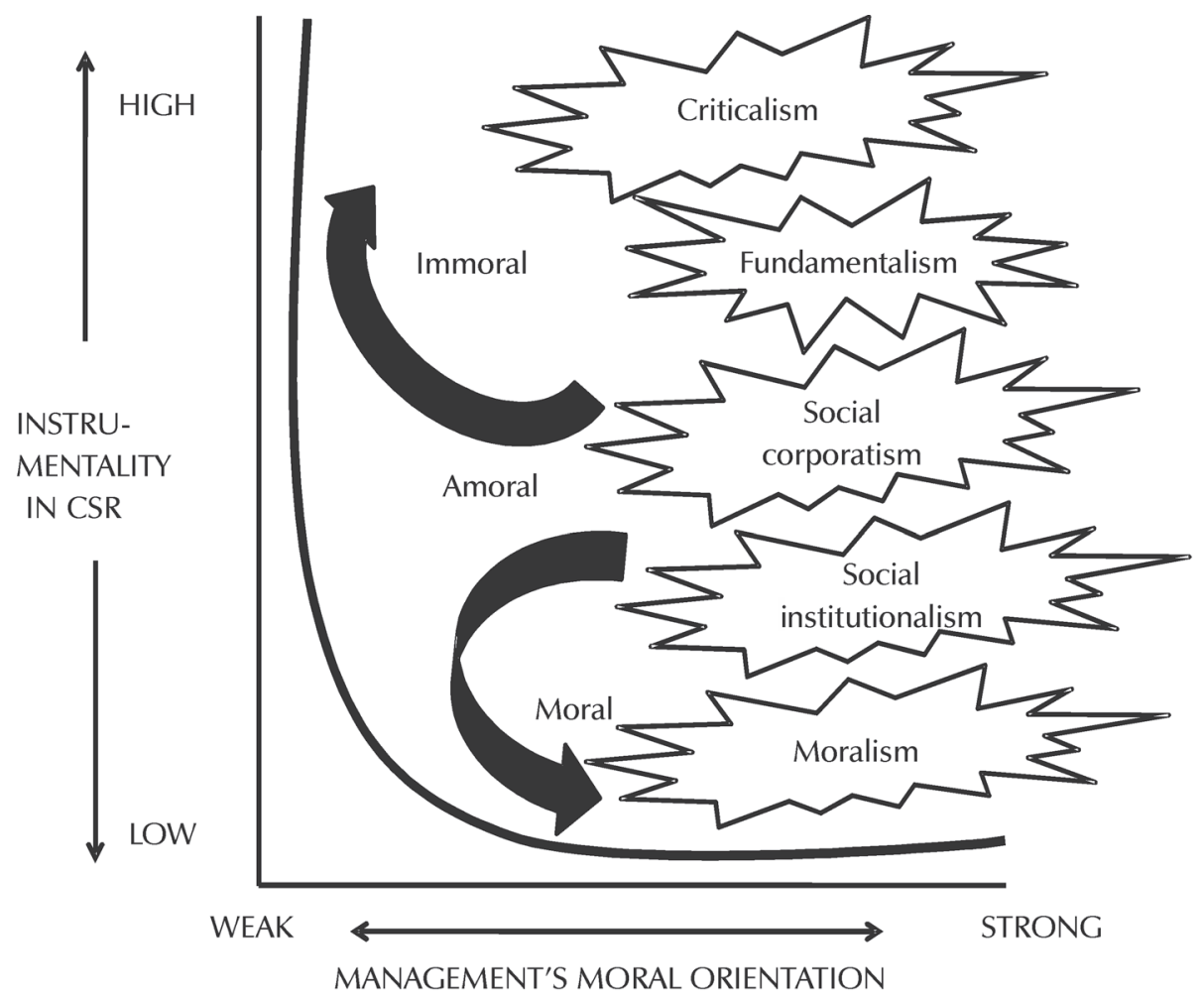

Criticalism (Carter \& Burritt, 2007) is indicated in Figure 1 as being associated with high levels of ethical instrumentality in CSR and immoral management orientations. Here company CSR reporting is regarded as a corporate tool aimed at diverting attention away from immoral management actions by 'green washing' stakeholders. CSR is used as a tool not simply to further the firm's profitability but to camouflage illicit managerial behaviour. In short, criticalism regards management's apparent concern with CSR as a deliberately insincere ploy used to divert attention away from its soft, illicit underbelly.

Fundamentalism is seen as high in instrumentality in the adoption of CSR and associated with a weak management moral orientation. Here CSR is regarded as beyond the corporate domain and that CSR is not the role of business but of government (Friedman, 1970). In this view, business does not have the right to meddle in matters that are the preserve of government. Far better that it should concentrate on maximising profits that are distributed through taxation by a democratically elected government holding the sole public mandate and vested moral authority to do so. On this basis any CSR performed by an organisation is insincere in terms of Bakan's (2004) typology. Figure 1 indicates management's orientation is considered morally weak in fundamentalism. Carr (1968) following Friedman (1970), suggests that any professed ethical action by management is a 'self-serving calculation in disguise' (Carr, 1968: 148) and thus is high in ethical instrumentality since it uses ethical initiatives (CSR) as a means to the common end of enhancing organisational profitability. 
Social corporatism is located in Figure 1 at middling levels of instrumentality and corresponds to an amoral management orientation. Here there is a neutral attitude to the 'sincerity divide'. While a dichotomy holds between management's business and social responsibilities, this theoretically constitutes neither a sincere nor an insincere management attitude to CSR. However, since the widespread adoption of the 'business case' in CSR in the social corporatist approach means high levels of managerial instrumentality are assumed, an insincere managerial orientation may arise with a propensity to spiral further downwards.

Social institutionalism occupies a 'sincere' position in terms of Bakan's (2004) divisional typology. This aspect is clearly indicated in the model (see Figure 1) where management's moral orientation is 'strong' and ethical instrumentality 'low'. Here business is expected to fulfil its social responsibility to maintain its legitimacy and function effectively.

Similarly, moralism advocates an approach to CSR which is 'sincere', low in managerial ethical instrumentality and high in moral strength (see Figure 1). Moral management is essential and the social responsibility of business paramount in this context.

In short, the heuristic suggests that as the level of instrumentality in CSR increases the more CSR is used as a business tool to increase profits and the more immoral management's orientation becomes. Possibly even ultimately becoming as Criticalists suggest nothing other than a smokescreen to hide illicit activity,

As mentioned earlier, average levels of moral development in managers are assumed to be 'conventional' (Kohlberg, 1981) and most are regarded as operating with an amoral orientation. Thus the heuristic suggests that higher levels of instrumentalism towards CSR demanded by certain organisations offers little scope for management to make ethical decisions freely, and may push amoral and moral managers into forms of immoral behaviour in CSR and, potentially, other more general spheres of management practice.

\section{5}

\section{Summary}

This paper has attempted to show how different levels of instrumentality in CSR applications are associated with constraints on managerial ethical freedom and specific managerial moral orientations. Different CSR approaches have been outlined and discussed and categorised in terms of Bakan's (2004) moral divide. Of particular interest is how the instrumentalism in CSR advocated by social corporatism (arguably the dominant approach in today's business world) is likely to have had two basic effects on management's moral orientation. First, it has had the effect of blurring the distinction between ethical and business action and making the two more or less indistinguishable from each other. Here there is a 'business case' for the incorporation of ethics in a firm's quest to enhance profitability. Second, by imposing such a requirement on management (i.e. that CSR should be adopted to promote profits) it pushes CSR, which embodies the ethical profile of a firm, into the realm of business in the criticalism/fundamentalist sense and broaches the sincerity divide. It thus becomes a kind of 'mauvais fois' where management is required to act out an insincere role that may in time spread throughout the business and corrupt it. In such situations, since management must adopt a business-like profit oriented approach to ethics, this imposition on its decision-making function generates situations in which it can no longer operate with sufficient flexibility to make coherent ethical decisions for which it might be held fully accountable. When CSR, the public ethical face of an organisation, is considered instrumentally like any other business tool to be exploited for its profitability, and managers are debarred from exercising their responsible judgement (even in a sphere central to the organisation's social reputation) it is conceivable that this orientation, ultimately, may also pervade other areas more distant from this ethical core. 


\section{6}

\section{Conclusion and recommendations for further research}

Several courses of action are suggested from the foregoing analyses. First, the instrumental profit oriented attitude of business in its fulfilment of its economic responsibilities should not be carried over into CSR issues. This is because such an approach may weaken managements' moral orientation and debar it from making decisions other than those that increase the profit of the firm. Management may thus ultimately be led to dispense with its ethical responsibilities altogether and use only those that seem strategically likely to enhance profits and perhaps regressing later to using them cynically as a smoke screen to hide immoral behaviour.

Second, while it has been suggested that firms with strong ethical reputations attract better employees and management (Coldwell et al., 2008), levels of ethical development and acumen among managerial staff should be assessed, both with regard to selecting persons with the necessary level of integrity and responsibility for managerial/leadership roles in organisations and with a view to initiating appropriate training for those who require it. In this way, the degree of freedom or constraint on individual manager's ethical decision making in business issues can be made to fit specific individual levels of moral development.

Third, the analysis of instrumentality in CSR and its likely effects on the moral orientation has suggested that managers, if they are to function ethically in Foucault's terms, must be empowered to do so by the creation of an organisational climate that enables them to act flexibly and responsibly in specific contexts requiring ethical judgement.

Training and sensitising managers to ethical behaviours and practices, whether at Business Schools or in-company, or promulgating elaborate ethical codes are unlikely to be of much use in counteracting unethical behaviour (Clark \& Leonard, 1998), if managers are not given the scope to operate with freedom inside a flexible framework of governance that allows and upholds such behaviour. And as noted earlier, the degree of this flexibility and particular emphasis placed on freedom versus governance in specific circumstances will depend on the level of moral development that an individual manager has attained (Kohlberg, 1969, 1981). Lower levels of moral development may require more governance than freedom and although moral development is difficult to measure such tools are currently available (see for example, Rest, 1986).

These suggested prescriptive remedial steps assume the heuristic outlined in this paper is valid and since this has not yet been established empirically it becomes the next course of envisaged research action. In this regard, it is recommended that a longitudinal quasi-experimental design be initiated whereby a company that initiates CSR instrumentally through social corporatism is contrasted with a company where moralism prevails and one where CSR activity and decision making are kept distinct from the business of profit making. Management's individual levels of ethical development in both companies would be measured and compared and the effects of the contrasted managerial approaches to CSR on the efficacy of CSR initiatives on community development investigated. The latter would be measured as 'grass root' community reactions to specific CSR implementations, thus exposing the sincerity of the organisation's CSR implementations and the 'mauvais fois' or otherwise of its managerial behaviour.

\section{Acknowledgement}

1 I would like to thank the reviewers for their suggestions and insights in formulating this paper.

\section{References}

BAKAN, J. 2004. The Corporation: the pathological pursuit of profit and power, New York: Free Press. BARGER, R.N. 2000. A summary of Lawrence Kohlberg's stages of moral development. http://www. nd.edu/-rbarger/kohlberg.html (accessed 17 September 2005).

BARKER, J.R. 1993. Tightening the iron cage: concertive control in self managing teams. Administrative Science Quarterly, 38: 408-437. 
BOONE, L.E. \& KURTZ, D.L. 1994. Business and society, New York: Harper Collins.

BROWN, J. \& FRASER, M. 2006. Approaches and perspectives in social and environmental accounting: an overview of the conceptual landscape. Business Strategy and the Environment, 15: 103-117.

CARR, A.Z. 1968. Is business bluffing ethical?

Harvard Business Review, January-February: 143-153.

CARROLL, A.B. 1979. A three dimensional

conceptual model of corporate performance, Academy

of Management Review, 4: 95-505.

CARROLL, A.B. 1987. In search of the moral manager. Business Horizons: March/April.

CARROLL (1991) (p 192)

CARROLL, A.B. \& BUCHHOLTZ, A.K. 2000.

Business and society, (5 ${ }^{\text {th }}$ ed.) South-Western: Ohio.

CARTER, A.J. \& BURRITT, R.L. 2007. By whatever name: a typology of corporate social responsibility.

Journal of the Asia-Pacific Centre for Environmental Accountability, 13(4): 19-29.

CLARK, M.A. \& LEONARD, S.L. 1998. Can

corporate codes of ethics influence behavior? Journal of Business Ethics, 17: 619: 630.

COLDWELL, D.A.L. 2000. Factors influencing perceptions and expectations of corporate social performance in South Africa: an exploratory empirical study, South African Journal of Economic and Management Science 3(3): 446-458.

COLDWELL, D.A.L. 2001. Perceptions and expectations of corporate social responsibility: theoretical issues and empirical findings. South African Journal of Business Management, 32: 49-52.

COLDWELL, D.A.L., BILLSBERRY, J., VAN MEURS, N. \& MARSH, P.J.G. 2008. The effects of person-organization ethical fit on employee attraction and retention: Towards a testable explanatory model.

Journal of Business Ethics, 78: 611-622.

DAHLSRUD, A. 2006. How corporate social responsibility is defined: an analysis of 37 definitions, Corporate Social Responsibility and Environmental Management, 15(1): 1-13.

DION, M. 2001. Corporate citizenship as an ethic of care: corporate values, codes of ethics and global governance. In Andriof, A. \& McIntosh, M. (eds.) Perspectives on corporate citizenship. UK: Greenleaf Publishing Limited.

FOUCAULT, M. 1978. Governmentality. Faubion, J.D. \& Power (eds.) Essential works of Foucault, 1954-1984 III, New York: The New Press.

FOUCAULT , M. 1984. The ethics of the concern for the self as a practice of freedom. Ethics, subjectivity and truth. Rabinow, P. (ed.) New York: The New Press. FREDERICK, W., POST, J. \& DAVIS, K.E. 1992. Business and society. corporate strategy, public policy, ethics, ( $7^{\text {th }}$ ed.) London: McGraw-Hill.

FREEMAN, R.E. \& LIEDTKA, J. 1991. Corporate social responsibility: a critical approach. Business Horizons, July-August, 92-98.

FRIEDMAN, M. 1970. The social responsibility of business is to increase its profits. The New York Times Magazine, September 13: 33-38.

GHAURI, P.N \& GRONHAUG, K. 2002 Research methods in business studies: a practical guide, New York: Prentice-Hall.

HEINEMAN, B. 2009. Executives face up to inevitable changes. Bauer, J. Financial Times Special Report. 18 June: 1 .

IBARRA-COLADO, E., CLEGG, S.R., RHODES, C. \& KORNBERGER, M. 2006. The ethics of managerial subjectivity. Journal of Business Ethics, 64: 45-55.

JACKSON, T. 2000. Management ethics and corporate policy: a cross- cultural comparison. Journal of Management Studies, 37(3): 349-369.

KLONOSKI, R.J. 1991. Foundational considerations in the corporate social responsibility debate. Business Horizons, July-August, 9-18.

KOHLBERG, L. 1969. Stage and sequence. The cognitive development approach to socialization. Handbook of socialization theory and research, Goslin, D. (ed.) Chicago: Rand McNally.

KOHLBERG, L. 1981. The philosophy of moral development: Vol 1. Moral stages and the idea of justice. San Francisco: Harper \& Row.

KOTLER, P. \& LEE, N. 2005. Corporate social responsibility. New Jersey: Wiley.

LEA, R. 2002. Corporate social responsibility, Institute of Directors (IoD) member opinion survey. IoD: London. www.iod.com/.../regulation_publications_ policypapers_CSR20Report.pdf - United Kingdom (Accessed 12 December 2009).

MASTERS, B. 2009. Economic crisis sows seeds of change. Financial Times Special Report: Sustainable Banking. 4 June: 1

MCMURTRIE, T. 2005. Factors influencing the publication of social performance information: an Australian case study. Corporate Social Responsibility and Environmental Management, 12: 129-143.

MOIR, L. 2001. What do we mean by corporate social responsibility? Corporate Governance, 1(2): 16-22. O‘DONOVAN, G. 2002. Environmental disclosures in the annual report: extending the applicability and predictive power of legitimacy theory. Accounting, Auditing and Accountability Journal, 15(3): 344-371. PALAZZO, G. \& SCHERER, A.G. 2006. Corporate legitimacy as deliberation: a communicative framework. Journal of Business Ethics, 66: 71-88. PINNEY, C. 2001. More than a charity. building a new framework for Canadian. private voluntary 
sector relations. Private Voluntary Sector Forum, June. tamarackcommunity. ca/downloads/home/more-thancharity.pdf. (Accessed 12 December 2009).

POST, J.E., LAWRENCE, A.T. \& WEBER, J. 2002. Business \& Society: corporate strategy, ethics, public policy, (10 ${ }^{\text {th }}$ ed.) New York: McGraw-Hill.

RAHIM, M.A., BUNTZMAN, G.F. \& WHITE, D. 1999. An empirical study of the stages of moral development and conflict management styles, The International Journal of Conflict Management, 10(2): 154-171.

REST, J. 1986. Moral development: Advances in research and theory, New York: Praeger.

ROBBINS, S.P. 1994. Management, New Jersey:

Prentice-Hall.

SARTRE, J.P. 1993. Being and nothingness:

a phenomenological essay on ontology. Translated by

Hazel E. Barnes. Washington: Square.

SIMS, R. \& BRINKMANN, J. 2003. Enron ethics (or culture matters more than codes). Journal of Business Ethics, 45: 243-256.
TETT, G. 2009. Fool's gold: how unrestrained greed corrupted a dream, shattered global markets and unleashed a catastrophe. Little: Brown.

VAN MARREWIJK, M. 2003, Concepts and definitions of CSR and corporate sustainability: between agency and communion. Journal of Business Ethics, 44 (2/3): 95-105.

WARREN, R. 1993. Codes of ethics: bricks without straw? Business Ethics: A European Review, 2(4): 185-191.

WINDSOR, D. 2006. Corporate social responsibility: three approaches. Journal of Management Studies, 43(1): 93-113.

WOODWARD-CLYDE. 1999. Key opportunities and risks to New Zealand's export trade from green market signals, final paper, Sustainable Management Fund Project 6117. New Zealand Trade and Development Board: Auckland. http://www.mfe.govt.nz/withyou/ funding/smf/results/6117_final.pdf (Accessed, 12 December 2009) 